\title{
PENGETAHUAN DAN PENERAPAN SASARAN KESELAMATAN PASIEN PADA MAHASISWA SEMESTER 6 DI AKADEMI KEPERAWATAN ADI HUSADA SURABAYA
}

\author{
ISWATI \\ AKADEMI KEPERAWATAN ADI HUSADA SURABAYA \\ iswatisaja@gmail.com
}

\begin{abstract}
Patient safety incident can be done by nursing students when doing clinical practice in hospitals. This happens because of a lack of knowledge about patient safety. The purpose of this study was to identify the relationship between knowledge of patient safety with the implementation of patient safety in the $6^{\text {th }}$ semester student at the Academy of Nursing Adi Husada Surabaya. This type of research is correlational, variable research is knowledge of patient safety and patient safety application. Total population of 143 and the number of samples is 131. The sampling technique is used directly probability sampling type simple random sampling. Measuring instruments used questionnaires and observation sheets. Data analysis using the spearman rank test, ( $\alpha=$ $0.05, p=0.01, r=0.817)$ indicating Ho refused meaning that there is a relationship between knowledge and application of patient safety. Results of the study recommended the need for the provision of special courses on patient safety for students in the $6^{\text {th }}$ semester nursing Academy Adi Husada Surabaya.
\end{abstract}

\begin{abstract}
Abstrak
Insiden keselamatan pasien dapat dilakukan oleh mahasiswa saat melakukan praktik klinik di rumah sakit. Hal ini terjadi karena kurangnya pengetahuan tentang keselamatan pasien. Tujuan penelitian ini untuk mengidentifikasi hubungan antara pengetahuan tentang keselamatan pasien dengan penerapan keselamatan pasienpadamahasiswa semester 6 di Akademi Keperawatan Adi Husada Surabaya. Jenis penelitian ini adalah korelasional, variable penelitiannya adalah pengetahuan tentang keselamatan pasien dan penerapan keselamatan pasien. Jumlah populasi sebanyak 143 dan jumlah sampel adalah 131. Teknik sampling yang digunakan adalah probability sampling jenis simple random sampling. Alat ukur yang digunakan kuesioner dan lembar observasi. Analisis data menggunakan Spearman Rank Test, $(\alpha=0.05, \mathrm{p}=0.01, \mathrm{r}=0.817)$ hal ini menunjukkan Ho ditolak artinya terdapat hubungan antara pengetahuan dan penerapan keselamatan pasien. Hasil penelitian merekomendasikan perlunya pemberian mata kuliah khusus tentang keselamatan pasien bagi mahasiswa semester 6 di Akademi Keperawatan Adi Husada Surabaya
\end{abstract}

Keywords: Knowledge, Patient's safety, Nursing student

\section{PENDAHULUAN}

Keselamatan pasien merupakan prinsip dasar dari pelayanan kesehatan yang memandang bahwa keselamatan merupakan bagian penting dalam keperawatan dan hak bagi setiap pasien dalam menerima pelayanan kesehatan. ${ }^{1} \quad$ Sistem keselamatan pasien merupakan salah satu upaya pengendalian untuk mengurangi cidera di rumah sakit yang menjadi tanggung jawab semua pihak termasuk mahasiswa keperawatan sebagai calon tenaga kesehatan yang melaksanakan praktik klinik di Rumah Sakit. ${ }^{2}$

Mahasiswa yang melaksanakan praktik di ruangan merupakan bagian dari sistem dan dituntut untuk memiliki pengetahuan, kemampuan untuk melaksanakan tindakan sesuai prosedur, dan kesadaran yang tinggi terhadap keselamatan pasien. Mahasiswa juga dituntut untuk mampu bekerjasama dengan tim kesehatan lain serta dapat berkomunikasi dengan pasien dan keluarga pasien yang berkaitan dengan keselamatan pasien. ${ }^{3}$

Berdasarkan survey awal yang dilakukan peneliti terhadap 10 mahasiswa semester 6 pada 6-7 Pebruari 2014 didapatkan data 7 dari 10 mahasiswa pengetahuan tentang keselamatan pasien masih kurang, terutama pengetahuan tentang insiden keselamatan pasien dan pelaksanaan prosedur tindakan. Menurut Wadir I Bidang Akademik Akademi Keperawatan Adi Husada Surabaya, diketahui masih didapatkan 
adanya insiden keselamatan pasien yang dilakukan oleh mahasiswa berupa kesalahan dalam pemberian dosis obat kepada pasien. Namun kesalahan tersebut tidak sampai menimbulkan cidera pada pasien.

Faktor yang dapat mempengaruhi terjadinya insiden keselamatan pasien diantaranya, kurangnya pengetahuan dan ketelitian mahasiswa pada saat melaksanakan praktik di ruangan. Kurangnya pengetahuan dan ketelitian dapat disebabkan mahasiswa belum menerima materi tentang keselamatan pasien secara khusus/berdiri dalam satu mata kuliah, namun masih terintegrasi dalam materi kuliah yang lain, misalnya: Terkait obat dan cairan pada mata kuliah Kebutuhan Dasar Manusia (KDM), terkait risiko jatuh pada mata kuliah Keperawatan Anak dan Keperawatan Gerontik, terkait komunikasi yang efektif pada mata kuliah Komunikasi Keperawatan.

Dampak yang ditimbulkan jika mahasiswa yang praktik kurang pengetahuannya tentang keselamatan pasien, maka dikhawatirkan melakukan kesalahan tindakan yang akan menimbulkan terjadinya insiden keselamatan pasien. Misalnya: Memberikan obat pada pasien yang salah, pasien jatuh dari tempat tidur, melakukan tindakan yang tidak sesuai dengan prosedur, dan lain sebagainya. Adapun dampak yang paling parah yang dapat terjadi yaitu mengakibatkan kejadian sentinel.

Untuk menghindari dampak yang terjadi dari faktor-faktor tersebut, maka mahasiswa perlu mendapatkan materi khusus terkait keselamatan pasien, sehingga mahasiswa dapat meningkatkan pengetahuannya tentang keselamatan pasien, mahasiswa juga dapat mengikuti pelatihan atau seminar yang terkait dengan keselamatan pasien, pada saat penerapan praktik di ruangan clinical educator (CE) dan perawat lebih ketat memantau serta memberikan pengarahan kepada mahasiswa yang bertugas. Diharapkan juga pembimbing mahasiswa lebih menekankan tentang penerapan keselamatan pasien pada saat melakukan bimbingan. Berdasarkan latar belakang diatas, peneliti tertarik untuk mengidentifikasi hubungan pengetahuan dengan penerapan sasaran keselamatan pasien pada mahasiswa semester 6 di Akademi Keperawatan Adi
Husada

Surabaya.

\section{METODE PENELITIAN}

Jenis penelitian ini korelasional, dilakukan pada 17 April-20 Mei 2014. Populasinya semua mahasiswa semester 6 Akademi Keperawatan Adi Husada Surabaya yang berjumlah 143. Sampel penelitian 131 responden yang memenuhi kriteria inklusi. Menggunakan probability sampling yaitu simple random sampling. Analisis data menggunakan uji korelasi rank spearman dengan $\alpha=0.05$. Pengumpulan data dengan kuesioner untuk variabel independen pengetahuan tentang keselamatan pasien dan lembar observasi untuk variabel dependen penerapan sasaran keselamatan pasien. ${ }^{4}$

\section{HASIL PENELITIAN}

\section{Karakteristik Mahasiswa}

Mahasiswa rata-rata berumur 21 tahun, sebagian besar berjenis kelamin perempuan 119 (91\%).

Pengetahuan tentang Keselamatan Pasien

Tabel 1. Pengetahuan Tentang Keselamatan Pasien

\begin{tabular}{|c|c|c|c|}
\hline No. & Pengetahuan & Frekuensi & $\begin{array}{c}\text { Persentase } \\
(\%)\end{array}$ \\
\hline 1. & Baik & 28 & 21 \\
\hline 2. & Cukup & 92 & 71 \\
\hline 3. & Kurang & 11 & 8 \\
\hline & Jumlah & 131 & 100 \\
\hline
\end{tabular}

pengetahuan tentang keselamatan pasien cukup namun masih ada mahasiswa yang pengetahuannya kurang.

Penerapan Sasaran Keselamatan Pasien

Tabel 2 Penerapan Sasaran Keselamatan Pasien

\begin{tabular}{clcc}
\hline No. & Variabel & Frekuensi & $\begin{array}{c}\text { Persentase } \\
(\%)\end{array}$ \\
\hline 1. & Baik & 40 & 30.5 \\
2. & Cukup & 78 & 59.5 \\
3. & Kurang & 13 & 10 \\
\hline & Total & 131 & 100 \\
\hline
\end{tabular}

Tabel 2 menunjukkan bahwa penerapan sasaran keselamatan pasien oleh mahasiswa mayoritas baik dan cukup namun masih ada yang kurang. 
Tabel 3 Penerapan Subvariabel Keselamatan Pasien

\begin{tabular}{llcc}
\hline No. & Sasaran & Frekuensi & Persentase \\
& Keselamatan \\
& Pasien & & \\
\hline 1. & Identifikasi Pasien & & \\
& Baik & 89 & 68.0 \\
& Cukup & 0 & 0 \\
& Kurang & 42 & 32 \\
& Total & 131 & 100 \\
\hline 2. & Komunikasi Efektif & & \\
& Baik & & \\
Cukup & 20 & 15 \\
& Kurang & 31 & 24 \\
& Total & 80 & 61 \\
& & 131 & 100 \\
\hline Keamanan $\quad$ Obat & & \\
dan Cairan & & \\
& Baik & 77 & 59 \\
Cukup & 37 & 28 \\
Kurang & 17 & 13 \\
Total & 131 & 100 \\
\hline
\end{tabular}

4. Ketepatan Lokasi,

Prosedur, Pasien

Operasi

Baik $\quad 34 \quad 26$

$\begin{array}{lll}\text { Cukup } & 97 & 74\end{array}$

Kurang $\quad 0 \quad 0$

Total $131 \quad 100$

5. Pencegahan Risiko Infeksi

$\begin{array}{lll}\text { Baik } & 113 & 86\end{array}$

$\begin{array}{lll}\text { Cukup } & 18 & 14\end{array}$

Kurang $\quad 0 \quad 0$

Total $131 \quad 100$

6. Pengurangan

Risiko Jatuh

$\begin{array}{lll}\text { Baik } & 28 & 21\end{array}$

$\begin{array}{lll}\text { Cukup } & 47 & 36\end{array}$

Kurang $\quad 56 \quad 43$

Total $131 \quad 100$

Tabel 3 Menunjukkan penerapan identifikasi pasien, keamanan obat dan cairan, pencegahan risiko infeksi, dalam kategori baik sedangkan ketepatan lokasi, prosedur, pasien operasi dalam kategori cukup, komunikasi efektif pengurangan risiko jatuh, pengurangan risiko jatuh dalam kategori kurang

\section{Hubungan Pengetahuan tentang Keselamatan Pasien dan Penerapan Sasaran Keselamatan Pasien}

Tabel 4. Hubungan Pengetahuan tentang Keselamatan Pasien dan Penerapan Sasaran Keselamatan Pasien

\begin{tabular}{clcccc}
\multicolumn{6}{c}{ Sasaran Keselamatan Pasien } \\
\hline \multirow{2}{*}{ No } & \multicolumn{5}{c}{ Penerapan sasaran keselamatan pasien } \\
\cline { 2 - 6 } & Pengetahuan & $\begin{array}{c}\text { Baik } \\
(\%)\end{array}$ & Cukup (\%) & $\begin{array}{c}\text { Kurang } \\
(\%)\end{array}$ & Jml \\
\cline { 2 - 6 } 1. & Baik & $7(25 \%)$ & $18(64 \%)$ & $3(11 \%)$ & $28(100 \%)$ \\
2. & Cukup & $18(20 \%)$ & $65(71 \%)$ & $9(10 \%)$ & $92(100 \%)$ \\
3. & Kurang & $2(18 \%)$ & $3(27 \%)$ & $4(36 \%)$ & $11(100 \%)$ \\
\hline
\end{tabular}

Tabel 4 menunjukkan bahwa mahasiswa yang memiliki pengetahuan baik dan cukup cenderung melakukan penerapan sasaran keselamatan pasien dalam kategori baik dan cukup dan yang pengetahuanya cukup dan kurang penerapan sasaran keselamatan pasien juga cenderung kurang.

Berdasarkan uji korelasi rank spearman dengan $\alpha=0.05$, diperoleh nilai signifikansi sebesar 0.01 yang lebih kecil dari $\alpha=0.05$ dan nilai korelasi sebesar 0.817 hal ini menunjukkan Ho ditolak artinya terdapat hubungan antara pengetahuan dengan penerapan sasaran keselamatan pasien yang bersifat positif dan sangat kuat. ${ }^{6}$

\section{PEMBAHASAN}

\section{Pengetahuan Tentang Keselamatan Pasien}

Hasil penelitian menunjukkan sebagian besar mahasiswa semester 6 memiliki pengetahuan yang cukup tentang keselamatan pasien, namun masih ada yang pengetahuannya kurang. Faktor-faktor yang mempengaruhi pengetahuan tentang keselamatan pasien pada mahasiswa, antara lain: Usia, pendidikan, pengalaman, sumber informasi. ${ }^{5}$

Usia merupakan hidup individu yang terhitung saat mulai dilahirkan sampai berulang tahun, semakin cukup umur, tingkat pengetahuan dan kematangan seseorang akan lebih baik dan matang dalam berfikir/bekerja. ${ }^{5}$

Berdasarkan hasil penelitian didapatkan bahwa rata-rata usia mahasiswa semester $6 \mathrm{di}$ Akademi Keperawatan Adi Husada Surabaya adalah 21 tahun. Usia termuda 21 tahun dan usia tertua 24 tahun. Usia ini masuk dalam kategori usia dewasa. Pada usia dewasa ini mahasiswa mempunyai pengetahuan dan kemampuan yang cukup baik sehingga lebih mudah menerima berbagai informasi baik dari media maupun petugas kesehatan khususnya dosen, perawat senior atau dokter terkait tentang keselamatan pasien. Pada kondisi tersebut mahasiswa juga mempunyai kemampuan mencerna suatu masalah sehingga dapat meningkatkan pengetahuannya tentang keselamatan pasien.

Mahasiswa semester 6 belum pernah mendapatkan pendidikan/pelatihan/mata kuliah khusus tentang keselamatan pasien, hal ini dapat menjadi penyebab mahasiswa kurang 
pengetahuan tentang keselamatan pasien terutama terkait dengan enam sasaran keselamatan pasien. Adanya beberapa mahasiswa yang telah memiliki pengetahuan baik dan cukup hal ini karena materi tentang keselamatan pasien telah diberikan dibeberapa mata kuliah, misalnya: Terkait obat dan cairan pada mata kuliah Kebutuhan Dasar Manusia (KDM), terkait risiko jatuh pada mata kuliah Keperawatan Anak dan Keperawatan Gerontik, terkait komunikasi yang efektif pada mata kuliah Komunikasi Keperawatan.

Faktor lain adalah sumber informasi. Pengetahuan sangat dipengaruhi oleh sumber informasi. Informasi adalah kenyataan dengan melihat dan mendengar sendiri komunikasi seperti membaca surat kabar, mendengarkan radio atau melihat TV. Dengan demikian semakin dekat seseorang dengan sumber informasi akan semakin bertambah pula pengetahuannya. $^{5}$

Berdasarkan hasil penelitian didapatkan bahwa mahasiswa semester 6 di Akademi Keperawatan Adi Husada Surabaya memperoleh informasi tentang keselamatan pasien dari perkuliahan dan pengalaman praktik klinik di ruangan, bahkan tidak ada mahasiswa semester 6 yang memperoleh sumber informasi dari pelatihan.

\section{Penerapan sasaran keselamatan pasien}

Hasil penelitian tentang ketepatan identifikasi pasien menunjukkan 32\% kurang. Hal ini berhubungan dengan pengalaman mahasiswa yang masih kurang dalam mempraktikkan cara mengidentifikasi pasien. Mahasiswa jarang sekali yang melakukan identifikasi pasien secara mandiri dikarenakan identifikasi sudah terlebih dahulu dilakukan oleh perawat saat pasien masuk rumah sakit. Mahasiswa yang melaksanakan praktik klinik di rumah sakit masih ada yang mengidentifikasi pasien dengan menggunakan nama dan nomor kamar pasien, padahal penggunaan nomor kamar tidak boleh digunakan dalam melaksanakan identifikasi pasien.

Menggunakan "dua identitas pasien" harus mendapat perhatian dan harus selalu disosialisasikan kepada mahasiswa. Penggunakan dua identitas pasien jika akan melakukan prosedur memerlukan sedikitnya dua cara untuk mengidentifikasi seorang pasien, seperti nama pasien, nomor rekam medis, tanggal lahir, gelang identitas pasien dengan bar-code, dan lain-lain. Nomor kamar pasien atau lokasi tidak boleh digunakan untuk identifikasi. Proses identifikasi pasien dapat dilakukan dengan bertanya kepada pasien sebelum melakukan tindakan misalnya "nama ibu siapa?". Jika pasien menggunakan gelang tangan harus tetap dikonfirmasi secara verbal, seandainya pasien tidak dapat menyebut nama maka dapat menanyakan pada penunggu atau keluarga. Pasien yang tidak mampu menyebut nama, tidak memakai gelang dan tidak ada keluarga atau penunggu maka identitas dipastikan dengan melihat rekam medik oleh dua orang petugas. ${ }^{9}$

Sasaran keselamatan pasien yang kedua yaitu komunikasi efektif, dengan cara: Menulis secara lengkap instruksi atau hasil pemeriksaan yang disampaikan melalui telepon, membacakan kembali instruksi atau hasil pemeriksaan yang disampaikan melalui telepon. Komunikasi yang mudah terjadi kesalahan kebanyakan terjadi pada saat instruksi/perintah diberikan melalui telepon. $^{2}$ Komunikasi dokter dan perawat mempunyai peran penting dalam menentukan derajat kesehatan pasien, dan kualitas pelayanan yang diberikan. Semakin baik komunikasi diantara perawat dan dokter semakin baik hasil perawatan yang diberikan ${ }^{12}$

Hasil penelitian tentang komunikasi efektif menunjukkan $61 \%$ kurang. Hal ini berkaitan dengan pengalaman, belum semua mahasiswa pernah melakukan pelaporan secara langsung/telepon terkait kondisi pasien kepada dokter/petugas kesehatan lain. Dalam hal ini mahasiswa masih memerlukan pendampingan dari perawat. Topik komunikasi efektif sudah diberikan secara teori di perkuliahan, namun belum memberikan penekanan praktik komunikasi yang maksimal di Laboratorium Keperawatan. Komunikasi efektif ini menjadi salah satu keterampilan yang harus dikuasai oleh mahasiswa semester 6 pada pelaksanaan praktik klinik di semester 6, namun demikian tidak semua mahasiswa dapat mempraktikkannya sehubungan dengan situasi dan kondisi di lahan praktik. 
Sasaran keselamatan pasien yang ketiga adalah keamanan obat. Di unit perawatan ratarata terjadi 3.7 insiden kesalahan obat setiap enam bulan. ${ }^{3}$

Hasil penelitian tentang keamanan obat menunjukkan 59\% baik. Hal ini berkaitan dengan materi kuliah yang sudah pernah diajarkan di kelas sejak semester 1di Laboratorium Keperawatan serta didemonstrasikan sebelum pelaksanaan praktik klinik di rumah sakit. Mahasiswa semester 6 umumnya telah diberi kesempatan mempraktikkan melakukan pencampuran obat secara mandiri dan keterampilan pemberian obat kepada pasien pada saat melaksanakan praktik klinik di rumah sakit sejak semester 2. Namun demikian, keamanan pemberian obat tetap harus menjadi perhatian utama terutama obat yang berisiko tinggi. Terdapat enam obat yang berisiko terjadinya kesalahan, diantaranya: Insulin, heparin, opioid, injeksi kalium klorida atau konsentrat kalium fosfat. blocking agen neuromuskuler, obat kemoterapi. ${ }^{11}$

Sasaran keselamatan pasien yang keempat yaitu kepastian tepat lokasi, tepat prosedur, tepat pasien operasi, yaitu: Memverifikasi lokasi, prosedur, dan pasien yang benar, memastikan bahwa semua dokumen, foto (imaging), hasil pemeriksaan yang relevan sudah tersedia dan diberi label yang baik dan sudah dipampang, menandai lokasi operasi dilakukan atas satu pada tanda yang dapat dikenali dan perlu melibatkan pasien. Tanda tersebut harus digunakan secara konsisten di rumah sakit dan harus dibuat oleh operator/orang yang akan melakukan tindakan, dilaksanakan saat pasien terjaga dan sadar jika memungkinkan, dan harus terlihat sampai saat akan disayat. Menandai lokasi operasi dilakukan pada semua kasus termasuk sisi (laterality), multipel struktur (jari tangan, jari kaki, lesi) atau multipel level (tulang belakang). Pengkajian yang salah, tulisan tangan yang tidak terbaca, komunikasi yang kurang adekuat, dan kurang melibatkan pasien dalam proses penandaan dapat menyebabkan terjadinya kesalahan (salah operasi, salah prosedur, salah pasien. $^{2}$

Penerapan kepastian tepat lokasi, tepat prosedur, tepat pasien operasi sudah cukup (74\%). Mahasiswa semester 6 sudah pernah praktik di kamar operasi, mahasiswa juga pernah diajarkan cara mengisi format pengkajian pada pasien operasi dan hal-hal yang harus dipersiapkan sebelum pasien di operasi.

Sasaran keselamatan pasien yang kelima adalah menurunkan risiko infeksi, yaitu: Mencuci tangan yang tepat sebelum dan sesudah menyentuh pasien, sebelum dan sesudah tindakan atau aseptik, setelah terpapar cairan tubuh pasien, sebelum dan setelah melakukan tindakan invasif, setelah menyentuh area sekitar pasien atau lingkungan, dan menggunakan alat pelindung diri (APD), seperti: Sarung tangan, masker, tutup kepala, jas, sepatu pelindung, kacamata pelindung. ${ }^{2}$

Pelaksanaan pencegahan risiko infeksi sudah baik (86\%). Hal ini berkaitan dengan materi kuliah Asepsis yang sudah pernah diajarkan secara khusus dan didemonstrasikan sebelum pelaksanaan praktik klinik di rumah sakit. Mahasiswa semester 6 selalu ditekankan melakukan tindakan untuk mencegah terjadinya infeksi, seperti: Mencuci tangan sebelum dan sesudah melakukan tindakan keperawatan, memakai sarung tangan dan masker pada saat melakukan tindakan keperawatan, dan memakai sarung tangan steril pada saat melakukan tindakan yang steril.

Menurut Kemenkes (2011) pencegahan risiko pasien jatuh, yaitu: Menilai risiko jatuh pada semua pasien baru dan mengulang penilaian jika diindikasikan oleh perubahan kondisi pasien atau pengobatan dan lainnya, menindaklanjuti hasil pengukuran sesuai derajat risiko jatuh pasien guna mencegah jatuh serta akibat tak terduga lainnya. Mengevaluasi riwayat jatuh pasien termasuk obat dan telaah terhadap konsumsi obat, gaya jalan dan keseimbangan, serta alat bantu jalan yang digunakan oleh pasien.

Hasil penelitian tentang pencegahan dan penilaian derajat risiko jatuh menunjukkan $43 \%$ kurang. Hal ini berhubungan dengan pengalaman mahasiswa semester 6 yang belum pernah mempraktikkan cara melakukan pengkajian pasien jatuh dan melakukan penilaian jatuh pada pasien saat melaksanakan praktik klinik di rumah sakit. Materi kuliah tentang jatuh diberikan namun masih terintegrasi dengan beberapa topik yang lain pada mata 
kuliah Keperawatan Anak dan Keperawatan Gerontik.

\section{Hubungan Pengetahuan Tentang Keselamatan Pasien dan Penerapan sasaran keselamatan pasien}

Berdasarkan uji korelasi rank spearman dengan $\alpha=0.05$, diperoleh $\mathrm{p}=\mathrm{r} 0.01$ dan $\mathrm{r}=0.817$, hal ini menunjukkan Ho ditolak artinya terdapat hubungan antara pengetahuan dengan penerapan sasaran keselamatan pasien yang bersifat positif dan sangat kuat.

Mahasiswa yang memiliki pengetahuan baik dan cukup cenderung melakukan penerapan sasaran keselamatan pasien dalam kategori baik dan cukup dan yang pengetahuannya cukup dan kurang penerapan sasaran keselamatan pasien juga cenderung kurang.

Mahasiswa keperawatan sebagai calon tenaga kesehatan, harus memiliki pengetahuan dan kemampuan untuk melaksanakan tindakan keselamatan pasien. Berdasarkan fakta mahasiswa sudah mendapatkan materi perkuliahan yang digunakan sebagai dasar untuk melakukan suatu tindakan keperawatan atau praktik di ruangan, akan tetapi setelah dilakukan penelitian masih ada beberapa mahasiswa yang pengetahuannya kurang tentang keselamatan pasien. Hal ini disebabkan karena belum ada mata kuliah khusus tentang keselamatan pasien. Materi tersebut masih terintegrasi pada materi kuliah yang lain, sehingga membuat mahasiswa kurang mampu memahami lebih jelas tentang keselamatan pasien terutama enam sasaran keselamatan pasien. Mahasiswa juga belum pernah mendapatkan pelatihan dan penyuluhan secara khusus tentang keselamatan pasien. Mahasiswa hanya pernah mendapatkan pelatihan tentang kegawat daruratan.

Dampak yang ditimbulkan jika mahasiswa memiliki pengetahuan yang kurang tentang keselamatan pasien terutama enam sasaran keselamatan pasien, dikhawatirkan akan melakukan kesalahan tindakan yang dapat menimbulkan terjadinya insiden keselamatan pasien.

\section{SIMPULAN DAN SARAN}

Terdapat hubungan antara pengetahuan tentang keselamatan pasien dan penerapan sasaran keselamatan pasien pada pada mahasiswa semester 6 di Akademi Keperawatan Adi Husada Surabaya.

Mahasiswa diharapkan dapat mempelajari ulang materi terkait enam sasaran keselamatan pasien yang sudah diberikan di semester sebelumnya, sehingga dapat meningkatkan pengetahuannya tentang keselamatan pasien terutama terkait enam sasaran keselamatan pasien yang akan berguna saat praktik klinik.

Akper Adi Husada hendaknya dapat memberikan materi secara khusus terkait keselamatan pasien menjadi suatu mata kuliah tersendiri serta mengadakan pelatihan atau penyuluhan terkait keselamatan pasien.

\section{DAFTAR PUSTAKA}

1.

Kemenkes RI. 2011. Peraturan Menteri Kesehatan Republik Indonesia Nomor 1691/MENKES/PER/VIII/2011 tentang Keselamatan Pasien Rumah Sakit. Jakarta: Depkes RI.

2. Clancy, C. 2011. New research highlights the role of patient safety culture \& safer care. Journal of nursing care quality/ JuliSeptember.

3. Sugiyono. 2007. Metode Penelitian Kuantitatif Kualitatif. Bandung: Alfabeta.

4. Notoatmodjo, S. 2010. Metodologi Penelitian Kesehatan. Jakarta: Rineka Cipta.

5. Arikunto, Suharsimi. 2006. Prosedur Penelitian Suatu Pendekatan Praktis. Jakarta: Salemba Medika.

6.

Kemenkes RI. 2008. Panduan Nasional Keselamatan Pasien Rumah Sakit (Patient Safety): Utamakan Keselamatan Pasien. Jakarta: Depkes RI.

7.

KP-RS. 2008. Panduan Nasional Keselamatan Pasien Rumah Sakit. Jakarta: Depkes RI.

8 .

SUPN Dr. Cipto Mangunkusumo. 2011. Buku Saku Quality \& Safety. Jakarta: Unit 
Pelayanan Jaminan Mutu RSUPN Dr. Cipto Mangunkusumo.

9. Sammer, C., Lykens, K., Singh, K., Mains, D., \& Lackan, N., (2010). What is Patient Safety Culture? A Review of the Literature. Journal of Nursing Scholarship, 42:2, 156165.

10. Cohen.2007. Protecting patients from harm: Reduce the risks of high alert drugs. http://www.nursing2007.com.

11. Manojlovich, M. et al. 2007. Healthy work environment nurse-phycisian communication \& patient outcomes. American journal of critical care. Vol. 16.

12. Potter, P.A. \& Perry, A.G. 2010. Fundamental of nursing: Concepts, process \& practice. St. Louis: Mosby Year Book. Inc.

13. WHO. 2007. WHO collaborating center for patient safety. Joint commission \& Joint commission international solution. http://www.who.int.com. 